\title{
obra en comunicación
}

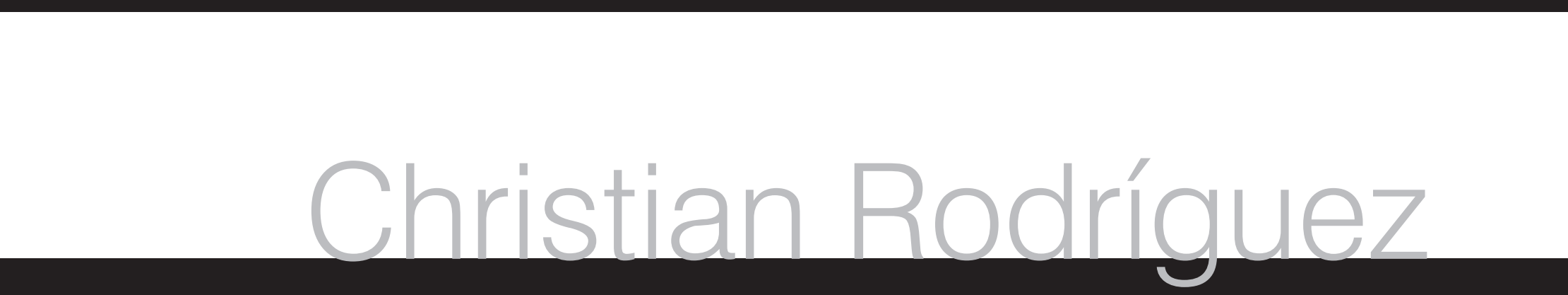

"En este proyecto estoy trabajando con las dos compañias más grandes de Vietnam. En el parque Lenin, donde se encuentra la Federación de Circo de Vietnam, son varias las protagonistas. En el edificio del circo, familias y artistas comparten habitación. En la que llamo 'el cuartito rosa', las paredes son de este color y todas sus habitantes son mujeres. En la antigua Saigón, hoy ciudad de Ho Chi Min, se encuentra el Grupo de Circo de Ho Chi Min. En su mayoría los artistas viven en un teatro abandonado. Debido a la exigencia física, con poco más de 30 años ya se retiran de la actividad diaria. Una caracteristica de la sociedad vietnamita es casarse a temprana edad. Si bien ninguno de estos artistas está casado, es probable que pronto lo estén."

Asi presenta Christian Rodríguez (Montevideo) esta serie de fotos para dixit. El autor se inició en la fotografía a los 20 años. Trabajó para varios medios nacionales e internacionales -diarios La República, Últimas Noticias, El Observador, y las agencias France Presse, AP, EFE y Reuters. Realizó campañas de moda y publicidad. En 2007 ingresó en el WIN-Initiative Stock. Al año siguiente ganó la beca Roberto Villagraz. Desde 2009 reside y estudia en Madrid. Ese mismo año recibió el Premio Futuro de su generación. www.christian-rodriguez.com
"I am working on this project with the two biggest companies in Vietnam. At Lenin Park, home to the Vietnam Circus Federation, several leading companies are to be found. At the circus building, families and artists share rooms. In what I call 'the little rose room' the walls are that color and all inhabitants are female. In the former Saigon, now called Ho Chi Minh City, one can find the Ho Chi Minh Circus Group. Most of the artists live in an abandoned theater. Due to the physical demands of the profession, artists in their early thirties have already retired from daily activity. Early marriage is a characteristic feature of Vietnamese society. Although all of them are single now, they will probablymarrysoon."

This is how Christian Rodriguez (Montevideo) presents this series of photos for dixit. He was introduced to photography when he was 20 years old. He has been employed in several national and international media, like newspapers (La República, Últimas Noticias, El Observador) and news agencies (France Presse, AP, EFE, Reuters). He has done fashion campaigns and ads. In 2007 he was admitted to the WIN-Initiative Stock photography collective. On the following year he won the Roberto Villagraz scholarship. Since 2009 he has been living and studying in Madrid. On that same year he received the Premio Futuro of his class. www.christian-rodriguez.com 


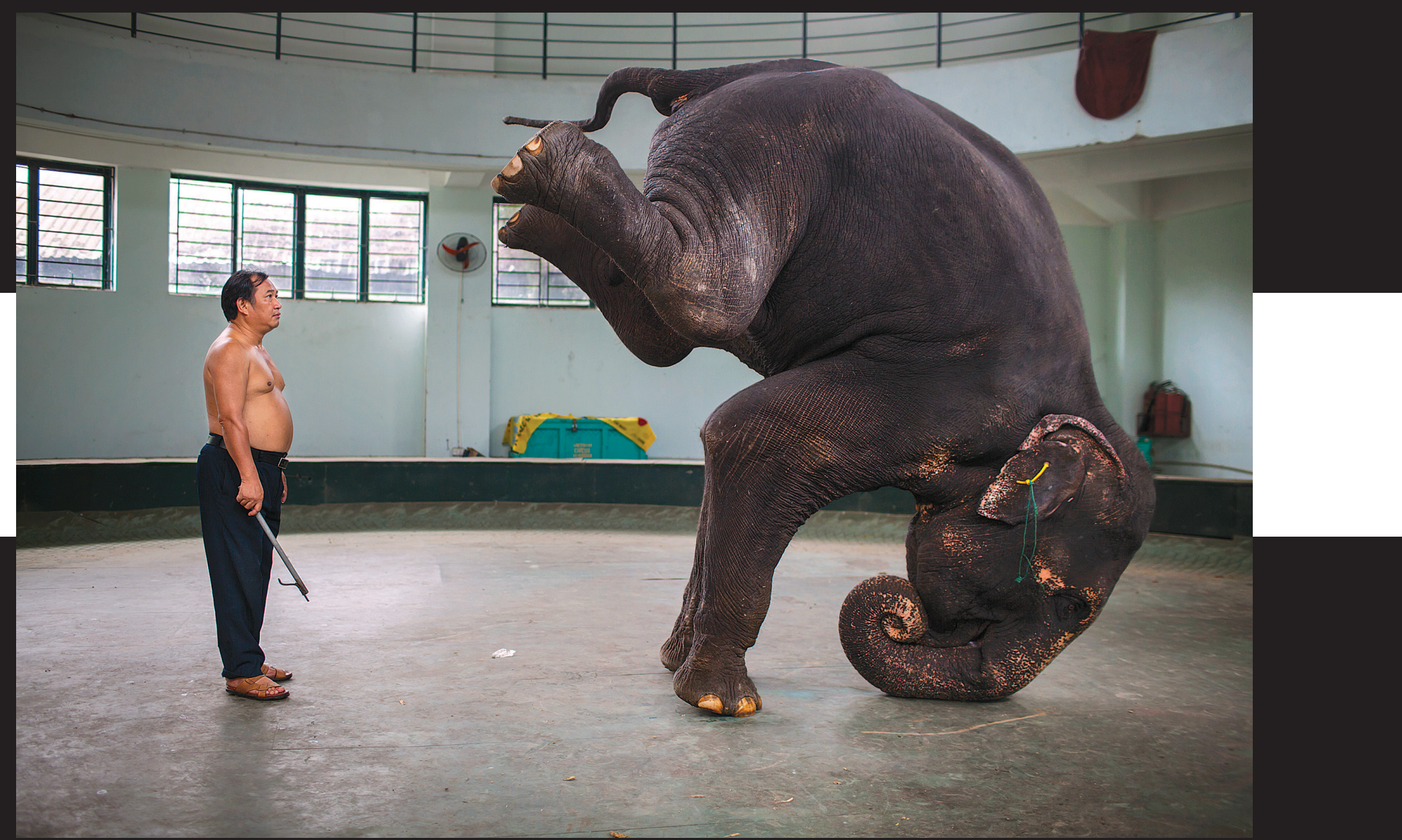



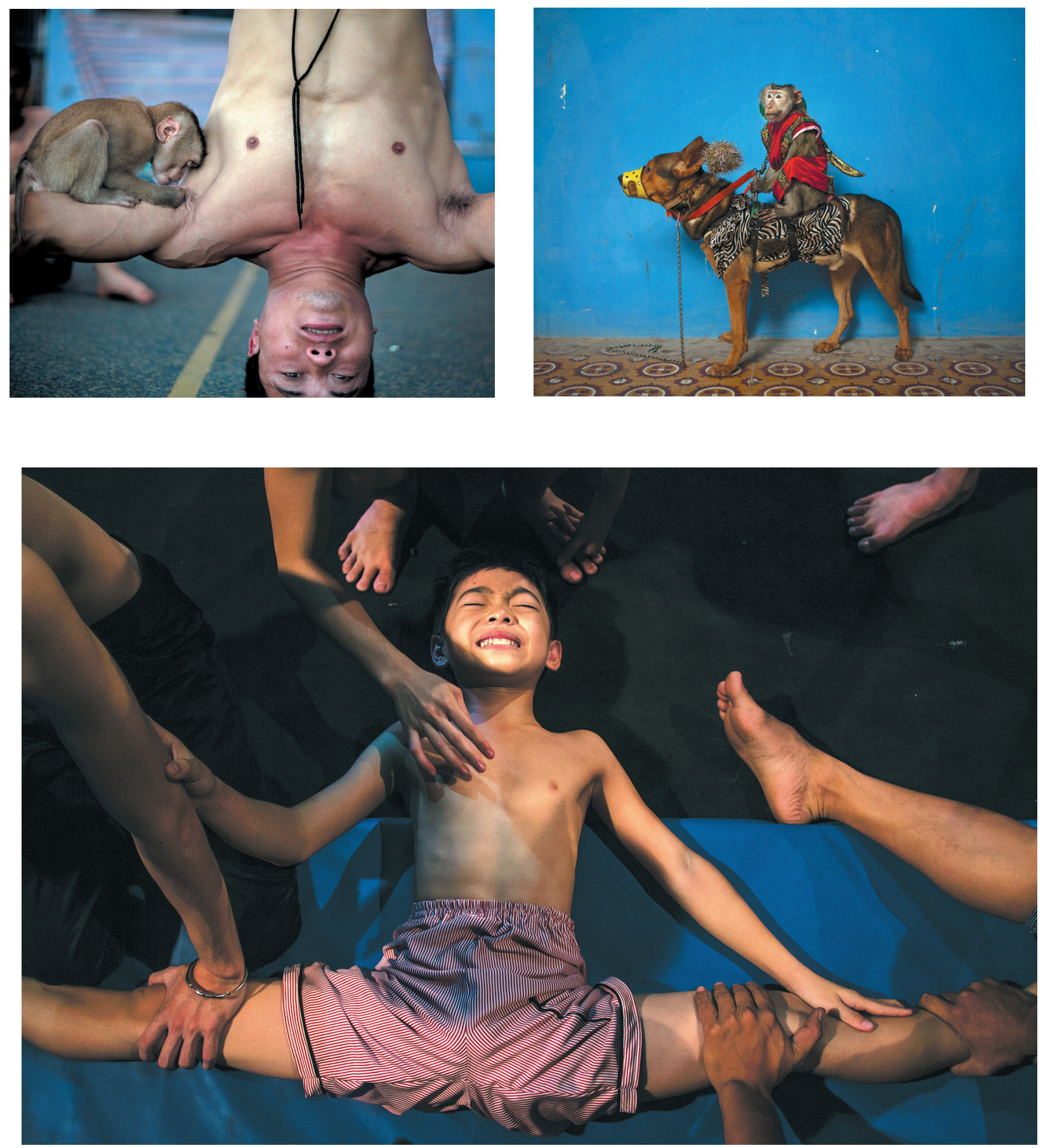


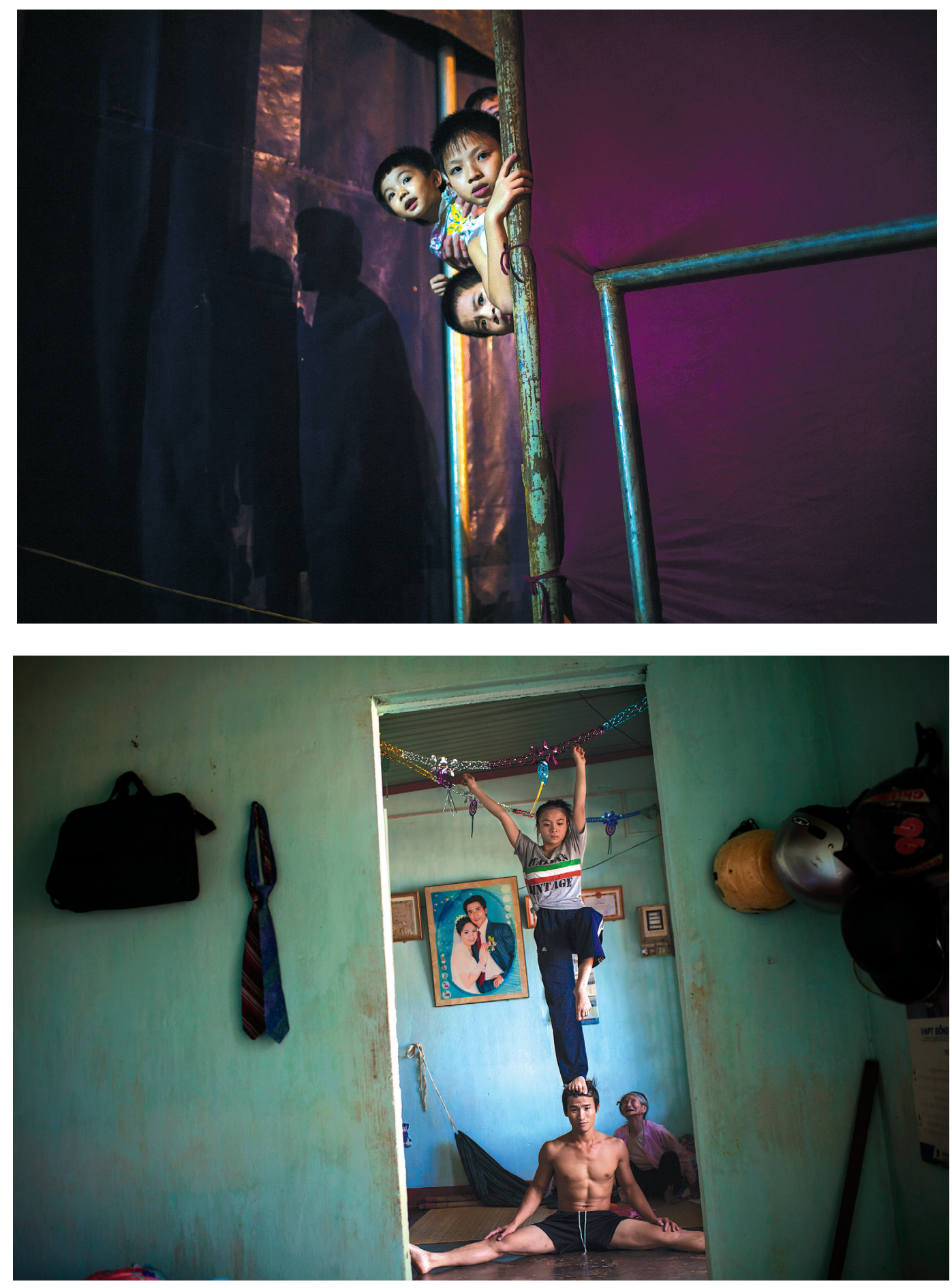



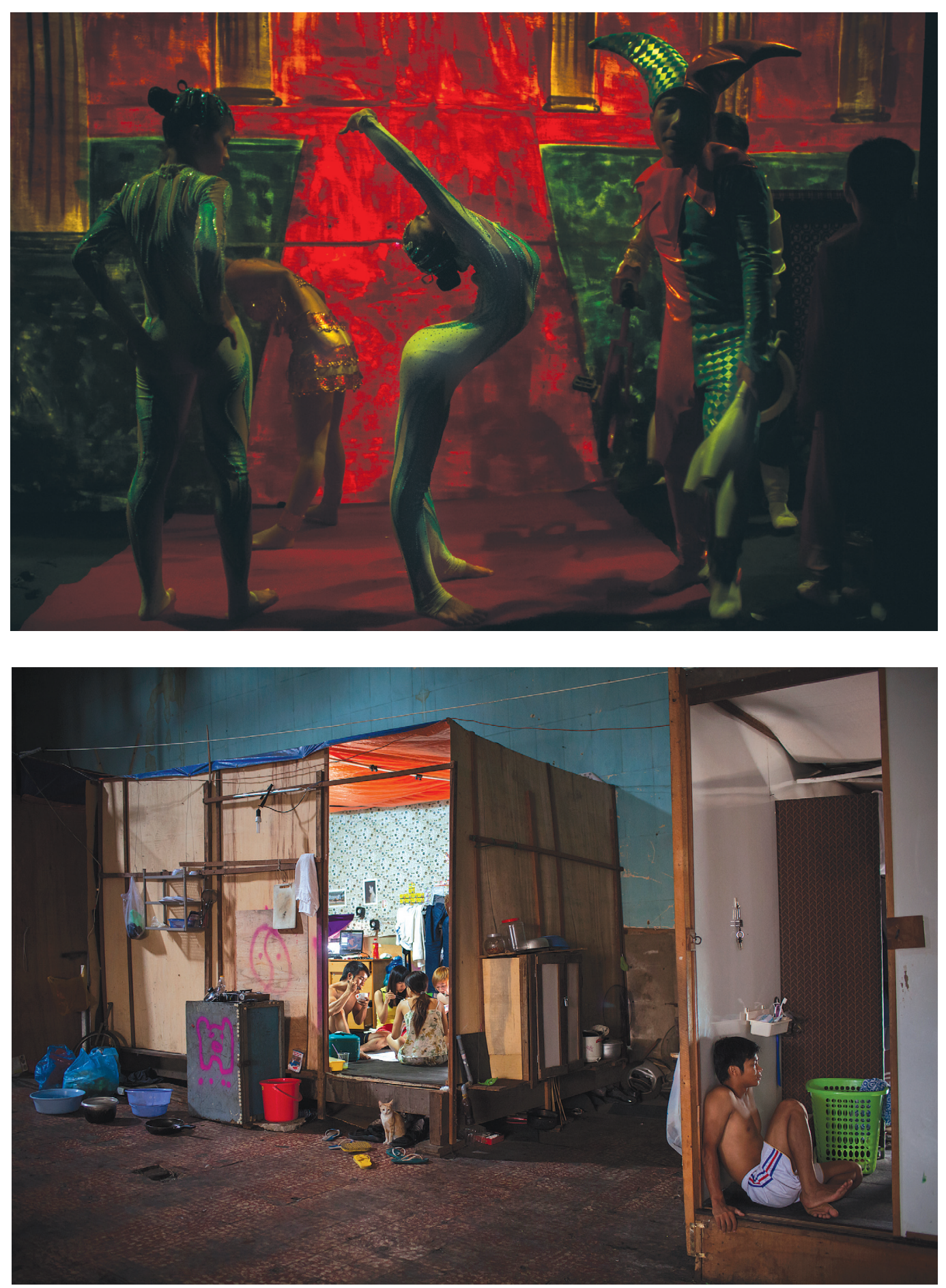

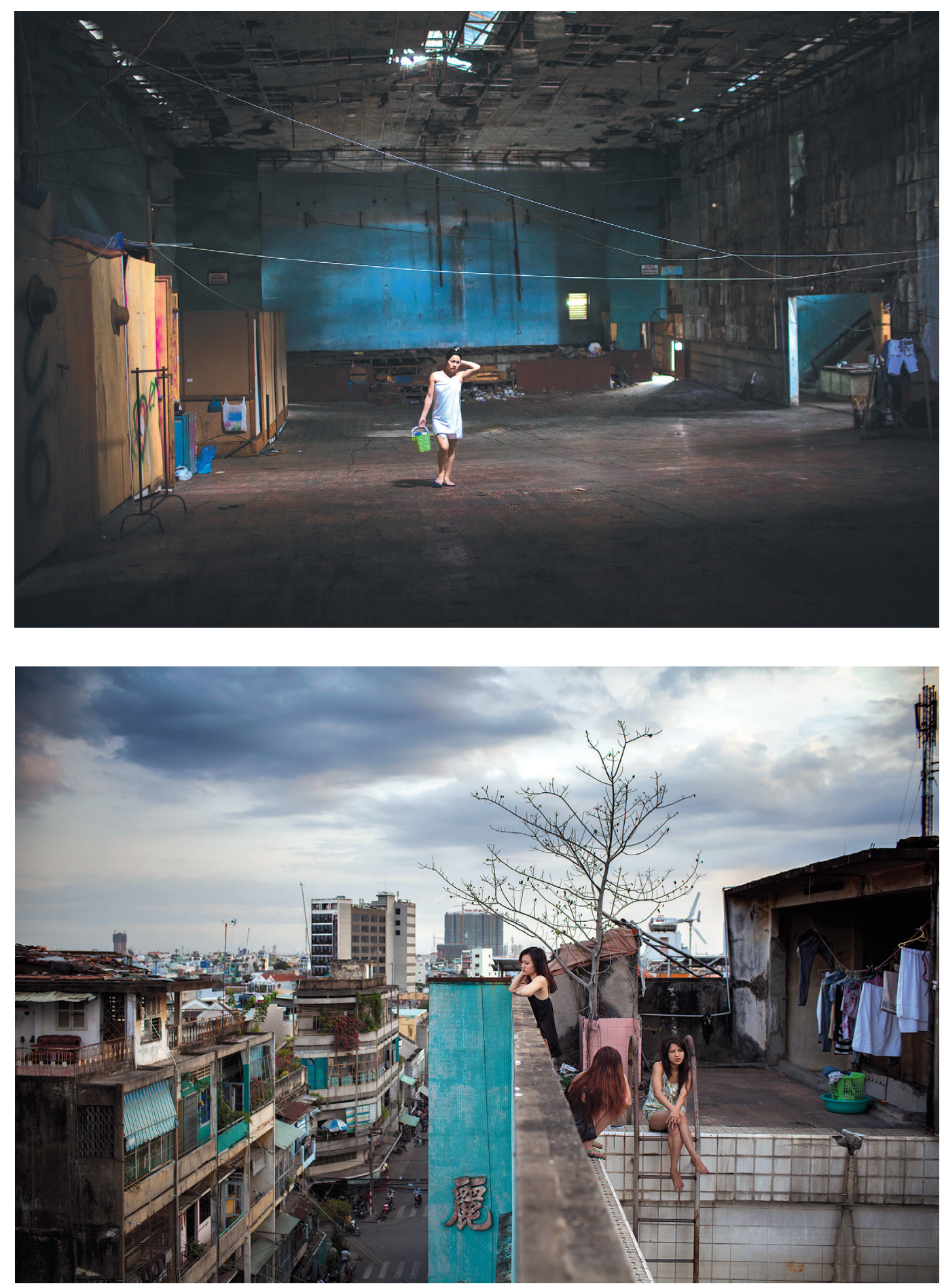